\title{
ПРОЕКТНА ТЕХНОЛОГІЯ: МОЖЛИВОСТІ ЗАСТОСУВАННЯ В ОСВІТІ
}

Коберник О. М. Проектна технологія: можливості застосування в освіті.

У статті обтрунтовано сутність педагогічного проектування та проектної технології, визначені загальні підходи до визначення етапів проектування; розкрито можливості використання проектної технології в навчальній та виховній діяльності, на уроках трудового навчання та у позаурочний час, у системі вищої педагогічної освіти.

Ключові слова: педагогічна технологія, проектна технологія, навчально-виховний процес, загальноосвітні школа, вищі навальні заклади.

Коберник О. М. Проектная технология: возможности применения в образовании.

В статье обоснована сущность педагогического проектирования и проектной технологии, определены общие подходы к определению этапов проектирования; раскрыты возможности использования проектной технологии в учебной и воспитательной деятельности, на уроках трудового обучения и во внеурочное время, в системе высшего педагогического образования.

Ключевые слова: педагогическая технология, проектная технология, учебновоспитательный прочесс, общеобразовательная школа, высшие учебные заведения.

Kobernik O. M. Project technology: application possibilities in education.

In the article the essence of the teaching of design and technology project to identify common approaches to defining the stages of project, revealed the possibility of using technology in project of educational and training activities, the lessons of labor training and after school, in higher education teaching.

Key words: educational technology, project technology, the educational process, schools, universities.

Постановка проблеми. Нові суспільно-економічні відносини в Україні викликали суперечність між соціальним запитом та можливостями сучасної системи освіти у розвитку особистості, між потребою в оновленні навчально-виховного процесу в сучасній середній та вищій школі та недостатнім рівнем впровадження інновацій. Сучасна філософія освіти докорінно змінює свою парадигму і потребує переходу до гуманістичної системи навчання та виховання.

На перший план у галузі навчання та виховання постають проблеми, що потребують обов'язкового оновлення, такі як: соціалізація, гуманізація та особистісна орієнтація педагогічного процесу; розвиток індивідуальності та суб'єктності вихованця; формування дитячого колективу й особистості та здійснення виховного впливу на особистість через клас, групу, колектив; задоволення постійної потреби вихованців у спілкуванні і взаємодії та будування взаємовідносин без конфліктів; індивідуальний підхід до особистості та іiі розвиток заради самореалізації у різних соціальних групах і суспільстві взагалі; вплив навчального, розвивального, виховного середовища тощо.

Уведення змін у практику навчання й виховання можливе за умови впровадження інноваційних педагогічних технологій, організації навчально- 
виховної роботи в закладах освіти на сучасних філософських, соціальних, педагогічних засадах.

У впровадженні освітніх технологій в педагогічний процес важливим $є$ встановлення у сучасному суспільстві пріоритету способу діяльності над результатом діяльності, 3 урахуванням соціальних, економічних, екологічних, психологічних, етичних та інших факторів і наслідків.

Із-поміж багатьох педагогічних технологій, які існують у педагогіці, окремо слід виділити ті технології, які в сучасній педагогічній теорії та практиці викликають особливий інтерес, де вагомого значення набуває проектна технологія.

Аналіз основних досліджень і публікацій. Педагогічне проектування феномен, що виник як результат взаємодії новітніх тенденцій у розвитку педагогічної теорії й інноваційної практики.

Багато видатних педагогів минулого, так чи інакше, торкалися проблеми проектної технології. Ретроспективний аналіз дослідження проблеми проектування у сфері освіти дозволив зафіксувати, що ряд важливих теоретичних ідей закладено у вітчизняній педагогіці у 20-ті роки XX століття (П. Блонський, С. Шацький та інші). У вітчизняній педагогічній науці фундатором цього напряму правомірно вважати А. Макаренка, який був переконаним прихильником проектування в людині найкращого.

У період 3 30-х до 60-х pp. ХХ ст. значно скоротилася кількість публікацій з методики та технології досліджень, сама тема педагогічних технологій заборонялася. Педагогіка мала пристосовуватися до командноадміністративної системи. У 60-ті pp. минулого століття у публікаціях знайшла відображення думка про необхідність формування нової наукової дисципліни - педагогічного проектування та появи спеціалістапроектувальника (Г. Щедровицький). Не зважаючи на це проектування ще довго не було предметом спеціальних досліджень.

У кінці 80-х рр. ХХ століття 3'явилася перша праця з педагогічного проектування В. Беспалько, яка символізувала визнання проектування та технології як самостійних видів педагогічної діяльності. Формування нових напрямків педагогічної науки кінця 80-х - початку 90-х рр. ХХ століття обумовило активізацію досліджень в області проектування. Фактично 3 цього часу воно стає самостійним предметом педагогічної науки та спеціально організованої діяльності. Починають складатися різні підходи до вивчення проектування як особливого механізму управління в освіті, як категорії дидактики, як алгоритму створення педагогічних систем.

Власне педагогічне проектування досліджувалося плеядою науковців, серед яких варто назвати В. Безрукову, В. Беспалько, В.Бондаря, Е. Заїр-Бек, О.Киричука, І. Підласого, Н. Суртаєву, Ю. Чернова, В. Юсупова та інших.

Та незважаючи на інтенсивні пошуки науковців 3 метою створення єдиної теорії, поки що залишаються не досить глибоко вивченими питання

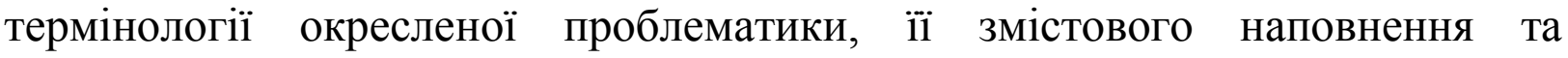
можливостей застосування. 
Мета статті полягає в розкритті сутності педагогічного проектування та можливостей iï застосування у навчально-виховному процесі середньої і вищої школи.

Виклад основного матеріалу. Варто зазначити, що методологія проектування в останні десятиліття зазнала значного поширення та розвитку. Власне кажучи, ми проектуємо щораз, коли розробляємо способи перетворення даної ситуації в іншу, більше прийнятну. У наш час загальновизнано, що будьяка перетворююча й творча діяльність людини може й повинна спиратися на методологію проектування або ії окремі процедури.

Визначаючи проект як прототип, ідеальний образ ймовірного або можливого об'єкту, стану; задум, план (projectio - кидання вперед), а проектування - як створення ідеального опису майбутнього об'єкта, що передує його реалізації, ми тим самим задаємо вектор розгляду педагогічного проектування як часткового випадку проектної практики в цілому.

Проектування передбачає в ідеальній формі результати як матеріальнопрактичної, так і духовної діяльності, тобто як зовнішнього, так i внутрішнього світу людини. Воно є правомірним для будь-якої діяльності в соціальній сфері, у тому числі педагогічної. Тому педагогічне проектування неможливо однозначно віднести до об'єктивних або суб'єктивних сторін педагогічної діяльності. Воно $є$ поліфункціональним, а в основі його цілісності лежить задум про вдосконалення педагогічної діяльності, про майбутній образ культуровідповідної, особистісно орієнтованої освітньої системи й відповідних їй педагогічних процесів.

Одні дослідники (В. Болотов, І. Ісаєв) пропонують розглядати педагогічне проектування як процес вирощування новітніх форм спільноти педагогів, учнів, нового змісту та освітніх технологій, способів педагогічної діяльності та мислення. Інші (В. Сластьонін, С. Шиянов) розглядають проектування як змістове, організаційно-методичне, матеріально-технічне та соціально-психологічне оформлення задуму та реалізації цілісного розв'язання педагогічного завдання, що здійснюється на інтуїтивному, дослідно-логічному та науковому рівнях. Треті (В. Беспалько) визначають проектування як багатокрокове планування, як діяльність по визначенню умов реалізації конкретної педагогічної системи. У деяких роботах (Н. Алєксєєв, В. Слободчиков) проектування в освіті розглядається як ідеальна побудова (задум) та практичне втілення можливого або обов'язкового.

Сучасний стан розроблення досліджуваної проблеми у вітчизняній педагогіці характеризується практико-орієнтованим розглядом педагогічного проектування як «важливого етапу діяльності вчителя, що прагне технологізувати навчально-виховний процес. Технологізувати педагогічний процес - це насамперед побудувати проект майбутнього процесу, що гарантує досягнення кінцевого результату. Спроектувати - це побудувати впорядковану систему технологічних процедур навчально-виховного процесу, обов'язкове виконання яких гарантує досягнення запланованого результату»[1]. 
Висвітлення особливостей розвитку теорії педагогічного проектування, контект-аналіз основних категорій дає змогу зробити такі висновки: незважаючи на інтенсивні намагання філософів, педагогів, психологів і методистів - створити системну теорію, поки що відсутнє цілісне визначення поняття «педагогічне проектування». Варто звернути увагу на концепцію Н. Яковлєвої, яка визначає такі характерні особливості педагогічного проектування:

1) цілеспрямована діяльність над створенням проекту як інноваційної моделі освітньо-виховної системи, орієнтованої на масове застосування. За якої словосполучення «створення проекту» не ототожнює проектування 3 процесами розробки, планування і прогнозування. Сутність проектування зміна дійсності;

2) процес створення проекту, що відображає розв'язання тієї чи іншої проблеми; діяльність в умовах освітнього процесу, що спрямована на забезпечення його ефективного функціонування й розвитку;

3) результат педагогічного проектування, яким є модель об'єкта педагогічної дійсності, що наділена системними властивостями i грунтується на педагогічному винаході, тому що в іiі основі - новий спосіб розв'язування проблеми, і вона передбачає можливі варіанти використання [8].

В узагальненому вигляді педагогічне проектування можна розглядати як колективну педагогічну діяльність, спрямовану на випереджувальне відображення педагогічної дійсності, що тісно пов'язане 3 педагогічним цілепокладанням, прогнозуванням, розробкою педагогічних теорій, концепцій, програм. Отже, педагогічне проектування - це процес проектування великих педагогічних систем, при якому необхідно відповісти на концептуальне (що треба зробити, змінити?), технологічне (як робити?), і кадрове (хто це зробить?) запитання. Водночас педагогічне проектування можна розглядати $i$ як індивідуальну діяльність учителя, спрямовану на попереднє розроблення основних елементів педагогічної ситуації чи цілісного педагогічного процесу: мети і завдань, плану, організаційних форм, методів і засобів, форм i методів контролю, корекції та оцінювання результатів педагогічної i навчальної праці.

Ми витлумачуємо таке визначення проектної діяльності як специфічного виду діяльності, спрямованого на створення суттєво нових продуктів, котрі $\epsilon$ результатом творчих пошукових зусиль особистості або колективу.

Об'єктом проектування $\epsilon$, як правило, визначена педагогічна конструкція: педагогічна система, процес, технологія, метод, прийом, завдання, ситуація чи зміст освіти, навчальна програма, підручник, навчальний посібник. Таке розмаїття пов'язане 3 тим, що в педагогіці багато процесів погано керовані, неоднозначні, i тому їхнє проектування здебільшого є малоефективним. Навіть маючи зовні традиційне вираження, об'єкт проектування має створюватись на новій ідеї. Потреба в проектуванні виникає за умови, якщо знайдено новий спосіб розв'язання існуючої 
проблеми. Створення відомого педагогічного об'єкта апробованим способом зводить проектування до рівня методичної розробки.

На основі аналізу сучасної педагогічної літератури (Г. Атанов, В. Безрукова, В. Коротов, Т. Новикова, І. Підласий, П. Решетников, В. Сластьонін та ін.) нами виокремлено такі види педагогічних проектів:

1) соціально-освітні проекти: проектування освітніх систем і процесів; проекти життєвої стратегії особистості, учнівських і педагогічних колективів;

2) навчальні проекти: навчальні завдання та ситуації, методи проектів на конкретних уроках; проекти індивідуальних навчальних програм;

3) виховні проекти: проекти в системі розвитку життєвої та діяльнісної компетентності учнів, їх соціалізації; культурологічні проекти;

4) технологічні проекти: творчі мережні проекти в навчальному закладі; проекти технологій навчання молодших (старших) школярів;

5) дослідницькі проекти: ігрові, інформаційні, телекомунікаційні, комп’ютерні проекти;

6) індивідуальні, групові та колективні проекти: особистісно орієнтовані, індивідуально-творчі, колективно-творчі проекти.

Варто зазначити, що відповідно до видів проектування можуть й визначатися й конкретні класифікації проектів.

Однією з провідних умов успішної стратегії розвитку освіти в державі, $\epsilon$ проектування соціально-освітніх систем і процесів. У сучасній педагогіці проектування соціально-освітніх систем і процесів застосовується досить широко. Тільки протягом останнього десятиріччя в Україні розроблено та реалізуються проекти позашкільної, дошкільної, загальної середньої освіти, професійно-технічної та вищої освіти. На думку, В. Штейнберга, формування технології проектування елементів освітніх систем і процесів охоплює три етапи. На першому «технологічна пам'ять» погоджується 3 ключовими «вертикальними» принципами системи освіти i 3 базовими компонентами освітніх технологій. Вертикальні принципи, що визначають найважливіші властивості всієї системи освіти, реалізуються на кожному 3 рівнів системи шляхом проектування базових елементів із заздалегідь заданими властивостями. На другому етапі формування технології визначається сукупністю чинників, від яких залежить іiі ефективність: призначення технології, призначення конструкторсько-технологічної діяльності учнів, принципи організації технології, склад технології, константи технології, інструменти технології, практика конструкторськотехнологічної діяльності. На третьому, заключному етапі, відбуваються безпосереднє створення та апробування проекту в різних його трансформаціях [7].

Навчальні проекти реалізуються, насамперед, за допомогою методу проектів - організації навчання, при якій в учнів формуються знання в процесі планування і виконання практичних завдань - проектів. Основні вимоги до застосування методу проектів:

1) наявність соціально чи особистісно вагомої проблеми, розв'язання 
якої потребує інтегрованих знань, дослідницького пошуку розв'язання;

2) теоретична, практична, пізнавальна значимість передбачуваних результатів;

3) самостійна (індивідуальна, парна, групова) діяльність учнів;

4) структурування змістової частини проекту (iз зазначенням поетапних результатів);

5) застосування дослідницьких методів (визначення проблеми і завдань дослідження, що випливають 3 неї, висування гіпотез для їх розв’язання, обговорення методів дослідження, оформлення результатів, аналіз здобутих даних, висновки) [6].

Виховні проекти: проекти в системі розвитку життєвої та діяльнісної компетентності учнів, їх соціалізації; культурологічні та ігрові проекти. Основна мета цих проектів (подій, ситуацій, процесів, заходів, програм, організацій, технологій) полягає в розв’язанні виховних завдань.

Технологічні проекти: творчі мережеві проекти в навчальному закладі; проекти технологій навчання молодших (старших) школярів. Творчі мережеві (блокові) проекти охоплюють оптимальну технологічну систему навчання, що сприяє максимальному розкриттю творчого потенціалу викладача та учнів при спільному досягненні поставлених навчальних цілей. Мережева (блокова) технологія навчання поєднує цілі, планування, зміст, форми і методи навчання, механізм його постійного стимулювання та відновлення.

Проекти технології навчання школярів мають велике значення для розвитку інноваційної педагогіки. Прикладом технологічного проекту навчання школярів може бути технологія «Випереджувальна педагогіка», створена на основі теорії розв'язування винахідницьких завдань (М. Меєрович, Л. Шрагіна, М. Глазунова).

Дослідницькі проекти: інформаційні, комп'ютерні, телекомунікаційні проекти. Вони потребують чіткої структури, обгрунтування актуальності теми, предмета дослідження для всіх учасників, визначення проблеми, мети. Цей тип навчальних проектів передбачає висунення гіпотези, іiі перевірку, обговорення та аналіз результатів, їх оформлення.

Дослідницькі навчальні проекти спрямовані на формування знань 3 наукових теорій, концепцій, ідей; усвідомленість та міцність знань, умінь, навичок та способів діяльності; уміння оперувати науковим понятійним апаратом; побудову власного алгоритму дій; творче застосування знань у незнайомій ситуації; оволодіння професійно значущими знаннями, уміннями і навичками, методами, прийомами, засобами діяльності, формами організації суспільно корисної роботи і вирішувати життєві ситуації. Останнім часом дедалі частіше під цим розуміють сучасну інформаційну технологію, що грунтується на електронному обробленні даних. На перший план висувається вивчення таких проблем, як: проектування діяльності, спрямованої на створення інформаційних продуктів; їх типологізація на основі визначення місця і ролі інформаційної діяльності в освіті; засоби іiі 
оцінювання і виміру. Загальноприйняте визначення поняття інформаційної технології зводиться, як правило, до процесу збирання, передачі збереження та оброблення інформації в усіх іiі можливих формах: текстової, графічної, візуальної та мовної.

Практико-орієнтовані навчальні проекти передбачають, що результат діяльності орієнтований на соціальні інтереси учасників та чітко визначений із початку. Цей тип навчального проекту має певну структуру діяльності учасників із зазначенням функцій кожного з них, а також чітку організацію координаційної роботи на кожному етапі. Продукт такого навчального проекту може бути різним - виріб, рекомендації до проведення наукових досліджень; висування ідей щодо модернізації певного виду діяльності; складання словника, визначника, історії тощо.

Предметні проекти проводяться в межах одного навчального предмета та потребують чітко визначеної мети, завдань, окреслення знань і вмінь, які необхідно опанувати.

Міжпредметні навчальні проекти характеризуються тим, що проблема може належати до двох або більше галузей знань. Вони потребують досить чіткої координації з боку спеціалістів, узгодженої роботи різних творчих груп, що мають конкретні дослідницькі завдання.

У процесі здійснення навчальних проектів 3 відкритою координацією педагог виконує свою функцію відкрито, але робить це без тиску; у навчальних проектах із завуальованою координацією вчитель виконує роль рівного учасника проекту.

Внутрішні чи регіональні навчальні проекти організовуються як у межах однієї групи, класу або групи, так і в межах країни в цілому. Міжнародні проекти здійснюються представниками різних країн.

Індивідуальні, групові й колективні проекти: особистісно орієнтовані, індивідуально-творчі і колективно-творчі проекти. Однією з вирішальних умов, що визначають успіх, наприклад, навчально-виховної роботи, $\epsilon$ індивідуальне проектування, тобто «безпосередня повсякденна робота учителів, викладачів, вихователів та наставників 3 планування практичних дій і програмування поведінки та діяльності учнів і вихованців» [5].

Індивідуально-творчий педагогічний проект - це теоретична i практична професійно-педагогічна діяльність, у результаті якої вчителями створюється авторська програма (ідея, концепція), що характеризується суб'єктивною, а іноді й об'єктивною новизною.

Колективно-творчі проекти передбачають розв'язання комплексного завдання, що охоплює організаційну, методичну, практичну, педагогічну, дослідницьку діяльність групи чи колективу фахівців, спрямовану на одержання інтегративного освітнього результату.

Перевагами парного та групового навчальних проектів $\epsilon$ те, що у проектній групі формуються навички співробітництва; кожен учасник відповідно до здібностей та якостей може бути лідером-генератором, лідером-дослідником, лідером-оформлювачем результатів, лідером-режисером 
презентації; є можливість організувати змагання між підгрупами, посилюючи мотивацію до отримання результату.

Усі проекти поділяються на: короткотривалі - протягом кількох днів; середньої тривалості - у межах одного місяця; тривалі - від кількох місяців до року.

Необхідно підкреслити той факт, що сучасна класифікація має досить чітко визначену, логічно побудовану структуру, а іiі втілення в освітню практику відбувається через інтеграцію різних видів навчальних проектів.

Одним із найважливіших моментів створення теорії педагогічного проектування $\epsilon$ визначення основних етапів процесу. Адже розроблення проекту здійснюється поступово з дотриманням певних етапів, кожен 3 яких вирішує відповідні завдання, має логічно завершений зміст, чітко визначені часові межі, а також передбачає різні за змістом види діяльності вчителя (викладача) та учня (студента).

Розвідки доводять, що у науково-педагогічній літературі наявна значна кількість підходів до поетапної організації створення навчального проекту.

Класичним вважається положення Дж. Джонсона про те, що процес проектування в своєму розвитку проходить три етапи: дивергенції (розширення меж проектної ситуації з метою забезпечення досить великого простору для пошуку способу розв'язання); трансформації (створення принципів і концепціі); конвергенції (вибір оптимального способу розв'язання із сукупності альтернативних).

Висновки. Отже, аналіз наукових джерел дає змогу констатувати, що існують різні підходи до визначення суті, структурних компонентів проектування в цілому й педагогічного проектування зокрема. Здебільшого науковці виділяють від трьох до семи і більше етапів проектної діяльності. На нашу думку, структура проектування передовсім визначається його об'єктом, оскільки етапи проектування навчання, виховання, трудової діяльності можуть мати дещо відмінну структуру, хоча у них прослідковуються й загальні підходи.

\section{Література}

1. Бондар С.П. Перспективні педагогічні технології в шкільній освіті / С.П. Бондар, Л.Л. Момот, Л.А. Липова, М.І. Головко - Рівне : Тетіс, 2003. - С. 30-31.

2. Коберник О.М. Проективна педагогіка і національна школа / О.М. Коберник // Шлях освіти - 2006. - № 7. - С. 7-9.

3. Коберник О.М. Проектування на уроках трудового навчання / О.М. Коберник // Трудова підготовка в закладах освіти. - 2001. - № 4. - С. 12-14.

4. Коберник О.М. Теорія і методика психолого-педагогічного проектування виховного процесу в школі / О.М. Коберник. - К. : Науковий світ, 2001. - 199 с.

5. Коротов В.М. Педагогическое проектирование и диагностика / В.М. Коротов. М. : Изд-во УРАО, 1999. - 153 с.

6. Новикова Т.А. Проектные технологи на уроках и во внеурочной деятельности / Т.А. Новикова // Народное образование. - 2000. - № 1. - С. 26-31.

7. Шишов С.Е. Проектный метод: проблемы и перспективы / С.Е. Шишов // Метод проектов в технологическом образовании школьников: [материалы Международного семинара]. - С-Пб. : Изд-во РГПУ им. А.И. Герцена, 2001. - С. 7-15.

8. Энциклопедия професионального образования. - М. : РАО, 1999. - Т. 2. - 348 с.

Стаття надійшла до редакції 23.05.2012 p. 